\section{Kjedelig anatomihistorie}

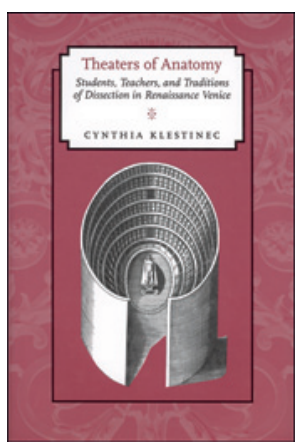

Cynthia Klestinec

Students, teachers, and traditions of dissection in renaissance Venice. 257 s, ill. Baltimore, MD: The Johns Hopkins University Press, 2011. Pris USD 55 ISBN 978-1-4214-0142-3

Kan anatomihistorie være kjedelig? Jo da, det finnes unntak - og denne boken er ett av dem. Dessverre, får man si, for den italienske renessansens anatomiundervisning er ikke bare full av spennende historie, men gir oss også forståelsen av fagets tidlige egenart, utvikling og sosiale posisjon. Det var nettopp der og da at den middelalderske skolastikkundervisningen - hvor professoren leste fra en av antikkens autores, mens en demonstrator sto for selve disseksjonen - ble avløst av en moderne form hvor anatomen selv dissekerte og forklarte til et fullsatt auditorium.

Den kaotisk-brokete forsamlingen man ser avbildet på forsiden til Andreas Vesalius' (1514-64) anatomibok fra 1543, ble i 1583 avløst av noe nytt: Et permanent anatomisk «teater» (dvs. tilskuerrom) ble bygd spesielt for anatomiundervisningen ved universitetet i Padua, Italia. Det er denne universitetsbyen og dens berømte anatomer - Vesalius' etterfølgere Realdo Colombo (1516-59), Gabriele Falloppio (1523-62) og Girolamo Fabrici (1533-1619) boken handler om.

Noen år senere ble dette teatret avløst av et større byggverk: en oval konstruksjon med gallerier i flere etasjer, hvor tilskuerne kunne stå og se ned på disseksjonen som foregikk på et bord nede i midten. Galleriene hadde ståplasser som var så trange at studentene knapt kunne komme forbi hverandre, og bare disseksjonsbordet var opplyst. En disseksjon kunne vare i en måneds tid eller mer og fant vanligvis sted i den kalde årstiden, mellom julen og karnevalet, av forståelige årsaker. Demonstrasjonene var uhyre populære og ble besøkt av leg og lærd.

I løpet av 1500-tallet ble universitetet i Padua besøkt av rundt 6000 utenlandske studenter, og mange av dem kom utelukkende for å følge undervisningen til de berømte anatomene der. Disseksjonsmaterialet var gjerne henrettede forbrytere - men bare de som ikke var hjemmehørende i republikken Venezia, som Padua tilhørte den gang.

I dag finnes det ikke mange slike «teatre» igjen (Uppsala har ennå sitt!), og det nærmeste vi i Norge kommer, er vel det halvsirkelformede, fredede «auditorium 13» i gamle Domus Medias østfløy.

Forfatteren er amerikansk litteraturprofessor med renessansen som spesialområde. På tross av at hun tidligere har publisert stoff om renessansens anatomi, bærer boken preg av å være skrevet av en ikke-medisiner. Stoffet er tørt og tungt for den som ikke kjenner stort til det fra før, og navn nevnes uten at bakgrunnen gis i tilstrekkelig grad. Eksempelvis nevnes den tyske studenten Baldasar Heseler, men ikke hans enestående beskrivelse av en Vesalius-disseksjon han fikk overvære i januar 1540 (1).

Boken, som er utstyrt med et 56-siders noteapparat og ikke mindre enn 277 litteraturreferanser, er etter mitt skjønn bedre egnet for litteraturhistorikere, i mindre grad for leger som ønsker å vite mer om renessansen og den gryende interesse for anatomien.

\section{En modig samfunnsmedisiner i Medellín}

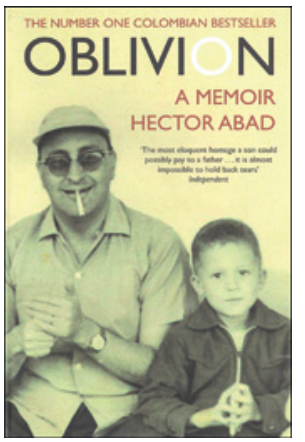

Héctor Abad Faciolince

Oblivion

A memoir. 272 s, ill. Brecon: Old Stree

Publishing, 2010. Pris GBP 17

ISBN 978-1-9069-6422-1

«In the house lived ten women, one boy and a man». Slik åpner denne selvbiografien. Gutten er den kjente colombianske forfatteren Héctor Abad Faciolince (f. 1958), og mannen er hans far. Og slik blir vi presentert for den usedvanlige sterke og fysiske kjærligheten mellom sønn og far i denne kvinnedominerte husholdningen, med bl.a. mor og fem søstre: «The boy, me, loved the man, his father, above all things. He loved him more than God.»

Boken handler om forfatterens far, legen Héctor Abad Gómez, født i 1921 og skutt av paramilitære i 1987. Dr. Gómez var bl.a. professor i samfunnsmedisin ved universitetet i Antioquia, Medellín, Colombia. Medellín var på denne tiden sterkt preget av vold, ikke på grunn av narkotika, det kom senere, men på grunn av de enorme klasseforskjellene. Dr. Gómez erklærte seg som kristen i religiøse spørsmål, marxist i økonomiske spørsmål og liberal i politiske spørsmål. Han var opptatt av den store befolkningen som levde i fattigdom, og arbeidet for å skaffe rent vann og sanitæranlegg. Politisk var han svært aktiv og kom i konflikt både med kirken og de konservative. Grunnet sitt sterke politiske engasjement måtte han tidvis arbeide i utlandet under WHOs beskyttelse. Han visste at han sto på en liste over folk som skulle likvideres, men fortsatte sitt arbeid mot de rikes grådighet og likegyldighet overfor de fattiges levekår.

I denne boken møter vi en annerledes familiefar. Hans kone må forsørge den store familien siden han gir bort pengene til sine studenter. Den store barneflokken oppdrar han etter mottoet: Hvis du ønsker at din sønn skal bli et godt menneske, gjør ham lykkelig. Hvis du ønsker at han skal bli et enda bedre menneske, gjør ham enda lykkeligere. Og vi møter en uredd politiker og engasjert samfunnsmedisiner.

Selv om dette er en selvbiografi, benytter forfatteren mange av romanens litterære grep, og boken kan også oppfattes som en roman. Språket er enkelt, ofte poetisk, særlig i beskrivelsen av Colombias vakre natur. Kirkens enorme makt illustrerer forfatteren ved hjelp av humor og ironi. Døden er et sentralt tema. Forfatteren blir allerede som guttunge tatt med av sin far til obduksjonssalen, en svært traumatisk opplevelse, som kommer tilbake til ham når han mange år senere befinner seg i den samme obduksjonssalen for å identifisere sin myrdete far.

Jeg anbefaler boken både fordi den gir et innblikk i et land der volden var i ferd med å ødelegge samfunnet, og fordi den forteller en spennende historie om en modig lege som gjennom sitt utrettelige arbeid for større sosial rettferdighet måtte bøte med livet.

\section{Karen Helene Ørstavik}

Avdeling for medisinsk genetikk

Seksjon for klinisk genetikk

Oslo universitetssykehus, Rikshospitalet
Per Holck

Institutt for medisinske basalfag

Universitetet i Oslo

\footnotetext{
Litteratur

1. Sundberg S. En märklig anatomibok i Stifts- och landsbiblioteket i Västerås. Nordisk medicinhistorisk årsbok 1973: 109-23.
} 